\title{
MONSTRUOS QUE GOBIERNAN, ANIMALES QUE DEVORAN. LA CRÍTICA AL LIBERALISMO DESDE LA ZOOLOGÍA POLÍTICA EN COSTA RICA (1870-1900)
}

\author{
Dennis Arias Mora
}

Recibido: 26/12/2014 Aceptado: 10/04/2015

\begin{abstract}
Resumen
Este artículo estudia las metáforas animales en el pensamiento crítico frente al liberalismo costarricense, a partir del caso de José María Figueroa (1820-1900) y su oposición al régimen de Tomás Guardia (1870-1882). Se propone que, en su sátira gráfica y textual, el autor conjugó su biografía como joven dibujante, "vagabundo" y conspirador, con posteriores saberes de carácter biopolítico, para elaborar un método definido aquí como abyecto que, oculto por la limitación autoritaria de la deliberación pública, develó lo monstruoso e infame en la arbitrariedad, corrupción, metafórica y épica del poder. Documentos de archivo, prensa, mensajes presidenciales y cuadernos personales permiten concluir que esta zoología política es la manifestación temprana de un lenguaje que no desaparece con la democracia.
\end{abstract}

Palabras clave: animalidad; monstruo; abyección; biopolítica; metáfora; zoología política.

\begin{abstract}
This article studies animal metaphors with a critical thinking against the Costa Rican liberalism. This is based on the particular case of José María Figueroa (18201900) and his opposition to the regime of Tomás Guardia (1870-1882). It is proposed that in his graphic and textual satire, the author combined his biography as a young painter, "vagrant", and conspirator with subsequent knowledge of biopolitical nature. He elaborates a method that is describes as abject. It is hidden by the authoritarian limitation of the public deliberation. The method reveals the monstrous and infamous arbitrariness, corruption, metaphoric, and epic of the power. Archive documents, printing press, presidential messages, and personal notebooks lead to the conclusion that the political zoology is the early manifestation of a language that does not disappear with the democracy.
\end{abstract}

Key words: animality; monster; abjection; biopolitics; metaphor; political zoology.

\section{Animales y monstruos como metáforas políticas}

Pensar, escribir y retratar lo político desde lo animal. La zoología política es un recurso en la tradición occidental del pensamiento sobre el Estado y el gobernar, una metáfora de expresiones textuales y gráficas (Peil, 1983) localizable en Centroamérica, 
pero poco estudiada por sus historiografías. En Europa puede aparecer dentro de los estudios de las metáforas políticas, ${ }^{1}$ mientras que en Costa Rica algunas expresiones de animalidad se han abarcado desde las artes (Alvarado y Hernández, 2006; Román, 2009) o desde el control social de la fiesta popular (Urbina, 2000). Este artículo propone que la animalidad impregna el pensamiento político, le sirve como metáfora para poner en cuestión el Gobierno, acercándolo a lo monstruoso. Ese pensar zoomórfico fue una de las expresiones fundamentales del saber crítico ante las contradicciones del liberalismo decimonónico, un saber no dominante, ni conceptualmente elaborado, sino sometido, sepultado como insurrección al poder (Foucault, 2001).

Es el extraño saber de José María Figueroa (1820-1900), polifacético personaje de quien se descubrieron recientemente unos cuadernos que satirizaron con animales la política liberal posterior a 1870. Sus textos combinaron versos e imágenes zoomórficas y monstruosas; las categorías de animalidad en su método remiten a partes estructurales del pensamiento político zoologizado en Occidente, a lo cual se suman historias de infamia para nombrar la corrupción política, creando con ello especies monstruosas. ${ }^{2}$

¿Monstruos en la política? Las metáforas han acompañado al texto político desde que existe, y su monstruo emblemático ha sido el Leviatán con que Thomas Hobbes representó el desarrollo del Estado europeo del siglo XVIII. Aunque tradicionalmente era reducida a retórica y ornamento, la metáfora es parte estructural de la comprensión humana y del actuar social, de modo que sus usos políticos no son inocentes, ni su estudio elude el análisis del argumento político, sino que lo complementa; al ser ilustrativas de una idea o estructurales al pensamiento político, las metáforas entrecruzan tradiciones filosóficas, literarias e iconográficas (González, 1998).

¿Por qué emerge la animalidad al monstrificar la política? La analista cultural Anne von der Heiden y el filósofo Joseph Vogl sostienen que la definición de animal político se refiere a un género donde lo humano es pensado desde una indeterminada bestialidad, un ser mezclado o en proceso, por ello concerniente a las deformaciones monstruosas. Con la indiferenciación entre bestia cazada y cazador bestializado, se crea toda una serie de figuras animales desde las cuales se puede problematizar el liderazgo, la comunidad y la ciudadanía políticas (von der Heiden y Vogl, 2007). En tal sentido, las categorías de la bestia y el soberano, a las que el filósofo Jacques Derrida (2010) dedicó su último seminario, son centrales en esa fabulación política y sustentaron ciertamente la crítica en Figueroa. Para estos autores, la problemática zoológica es reflejo de lo biológico en lo político, y en esa medida se relaciona con el biopoder, entendido por el filósofo Michel Foucault $(2001,2008)$ como esa racionalidad liberal que desde finales del siglo XVIII incorpora el bios al Gobierno, al administrar, calcular e intervenir la vida y las poblaciones. Esa gubernamentalidad crea un saber y, por ende, una verdad sobre el cuerpo individual y social. La experiencia latinoamericana de los saberes biopolíticos (eugenesia, higienismo, estadística) se extiende a lo largo del siglo 
XIX; los vínculos de Figueroa con ellos remiten al ejercicio de la mirada naturalista del territorio por gobernar, pero también del cuerpo de la política.

El conocimiento sobre Figueroa ha tenido dos impulsos recientes; primero, al ser trasladado a los Archivos Nacionales el conocido Álbum de Figueroa, ${ }^{3}$ compilación textual y gráfica de la historia, la cotidianidad y el espacio costarricense desde la colonia; segundo, al localizarse unos cuadernos ${ }^{4}$ en la biblioteca personal del expresidente Rafael Yglesias (1894-1902). Estos momentos generaron una amplia discusión sobre el valor patrimonial y artístico de los materiales. Sin embargo, los estudios historiográficos sobre Figueroa van al ritmo pausado con que su obra se revela. ${ }^{5}$ Considerando información en archivos, cuadernos, mensajes presidenciales y prensa, se analiza una temprana expresión de la zoología política del país y sus enlaces con el saber biopolítico, aspectos aún inexplorados. El artículo recoge parte de la biografía del autor y sus primeros encuentros con los tribunales, actividades que se combinaron con la mirada biopolítica del espacio para esbozar un método, entendido aquí de abyección para oponer al autoritarismo liberal la animalidad, la monstruosidad y la infamia.

\section{El arte de la obscenidad, la vagancia y la conspiración (1843-1855)}

Las transformaciones en la sociedad costarricense luego de la década de 1840 cruzaron de distintos modos la biografía de Figueroa: la separación de la Federación Centroamericana, la emergente economía agroexportadora del café, la consiguiente codificación legal y la construcción administrativa del Estado. Los mandatos de Braulio Carrillo (1835-1837, 1838-1842) gestaron varios de esos cambios que alcanzaron a Figueroa, como la promulgación del Código General en 1841 y las constantes regulaciones sobre la vagancia y el apremio laboral en tiempos de escasez de brazos y disciplinamiento capitalista (Sánchez, 2013).

Al aparecer en los registros judiciales de las décadas de 1840 y 1850, Figueroa se encuentra fuera de ley según el Código de 1841 y sus disposiciones en torno a los delitos contra las buenas costumbres, la seguridad del Estado y la honra y tranquilidad de las personas (Oficial, 1858). En el proceso realizado por difusión de dibujos obscenos de mujeres, en octubre de 1843 (Malavassi, 2005), los testigos, y el mismo Figueroa ante el peso de las evidencias, confesaron que él era el autor, quien vengaría así sus problemas con el padre de las mujeres, de apellido Alfaro. Describían a Figueroa "de mala conducta", "persona que inquieta la tranquilidad de los demás", "no tiene oficio"; mientras él afirmaba tener "profesión de dibujo".

Las láminas habían sido mostradas en un billar a unos hombres solteros, y se sospechaba también de su autoría en unos "pasquines insolentes", "libelos infamatorios" colocados en los vecindarios de la ciudad de Cartago; anunciaban el correr de la sangre, la "venganza de Morazán” y la venida de “los nicaraguas" para 
defender la memoria del "ilustre general". Al parecer Figueroa reclamaba por libertad de imprenta y que se revelara el "modo oscuro" del proceder de algunos jueces y funcionarios municipales de la ciudad, así como parecía integrar un plan conspirativo para robar dinero a familias adineradas y huir a El Salvador. Ni su participación ni su condena eran seguras (ANCR, octubre de 1843). ${ }^{6}$ Otro proceso en 1855 le costó a Figueroa ser expulsado del país por aparentes rumores provocados por él mismo sobre la "revolución del pueblo", un plan de atentado contra un general de apellido Montero que incluía comentarios sobre la opresión, la falta de libertad en el país y la necesidad de tener "hombres dispuestos", como en Nicaragua. De nada le valió al acusado afirmar el haber hecho tales declaraciones en broma, por "diversión" y entre copas, tampoco el haberse designado "comerciante"; tenido nuevamente por testigos como "vago y mal entretenido", como autor de delitos que quedaron impunes, y con presuntas rencillas con funcionarios del Gobierno, terminó expulsado del país y exiliado en Nicaragua (ANCR, abril de 1855).

Por su relevancia posterior de estas tempranas experiencias judiciales de Figueroa, conviene destacar la delimitación fluctuante del espacio de conspiración, un dato reiterado que evidencia el fresco acontecer de las disputas regionales por la disolución federal y sus incipientes Estados. Si bien Costa Rica se autodefinía por su contraste con los conflictos centroamericanos (Acuña, 2002), en el entorno de Figueroa se visualiza otro país donde la vecindad es admirada y el quehacer conspirativo y punitivo se sucede entre distintos puntos del istmo, incluido el suyo. Atentar contra el Gobierno o sus funcionarios implicaba quedar al margen del orden justo cuando la recodificación legal se extiende por todo el continente (Bravo, 2004) y los gobiernos de la región son disputados por facciones, de lo cual participa la familia Figueroa Oreamuno. Esta, radicada en Cartago, tenía una tradición de disputas políticas con la capital, San José, de allí su oposición a Braulio Carrillo y el apoyo a Morazán (Malavassi: 2005; Arias, 2011). El oficio de dibujante contraviene también el espíritu de la codificación y de la legislación de imprenta, cuya regulación constante desde la década de 1830 cuidaba del honor y de identificar (en la imprenta, no en la publicación) los anónimos (Oficial, 1846; Vega, 1995). Así, la ley alcanza al dibujante conspirador que denuncia lo público y ofende lo privado, futuras claves del saber zoo-biopolítico de Figueroa.

\section{El espíritu de empresa, los saberes y la mirada biopolítica (1880-1900)}

Se conoce poco de la trayectoria de Figueroa en las siguientes décadas; según el historiador Víctor Hugo Acuña (2011), su exilio transcurrió en Nicaragua hasta 1864, después de lo cual participó en expediciones por el territorio costarricense y, posiblemente, comenzó a elaborar su álbum. La marginalidad parece quedar atrás; y, así, ante las autoridades Figueroa ya no era de oficio dibujante sino "agricultor". 
En una época en que poblar el país y habilitar tierras y caminos significaba progreso, del cual el ferrocarril interoceánico era su principal símbolo, Figueroa y sus socios ofrecieron habilitar caminos entre el Valle Central y el sureste del país; algunos testimonios de la década de 1880 confirman esa relación entre "la felicidad del país" y las "fáciles vías de comunicación". Prometieron habilitar "tierras muy fértiles, de mucha riqueza" (ANCR, agosto de 1882), y pedían a cambio 200 caballerías de tierra en baldíos, pero la propuesta no fue aceptada, eso llevó a un proceso de reclamación que tuvo buen término para los proponentes y que renovaba la figura de Figueroa ante los poderes públicos:

no son capitalistas, pero son notoriamente conocidos por su espiritu de empresa y por su decisión y actividad en el ejercicio de proyecto de esa especie, conocen el terreno y han gastado mucho tiempo y algún dinero en exploraciones, sufriendo privaciones y fatigas, por lo cual debieran figurar en primer término y podría hacérseles la concesión sin mengua ninguna de dignidad y soberania (ANCR, setiembre de 1882).

Esas exploraciones dan pistas sobre el destino de Figueroa en décadas previas. Poco después propuso al Estado la venta de una carta geográfica del país; la oferta fue aceptada por la Comisión de Fomento del Congreso, que estimó cancelarle cuatro mil pesos. La petición revela un oportuno saber sobre el territorio en momentos de disputas fronterizas y de aspiraciones federales centroamericanas con alertas de guerra. Figueroa decía:

no tiene Costarrica una carta geográfica que represente todo cuanto su territorio abraza y encierra (...) son incompletas, confusas, con yerros de gravedad y llevadas a término por personas que sin conocer el país, han hecho fe en informar (...) nadie se ha dedicado a levantar una carta geográfica del país, exacta, precisa, circunstanciada, producto del amor al estudio y del amor a la Patria, ni el Gobierno está hoy en circunstancias pecuniarias que le permitan la adquisición de un mapa científico, dispendioso en tiempo y en dinero (...) habiendo concluido el infrascrito un mapa de la República de Costarrica, fruto de su trabajo perseverante por espacio de cuarenta años empleados en viajar por las montañas atravesando escabrosidades y vadeando ríos caudalosos y de rápidas corrientes, penetrando por sus bocas, bosquejando lo sinuoso de sus costas; desafiando en estas correrías escaseses y peligros; expuesto a las inclemencias de la naturaleza y a las inclemencias y rigor salvaje de los indios (...) toca a ustedes Soberano Cuerpo la propiedad de esta carta geográfica para el arreglo de límites con otros países y en el interior del país, para la enseñanza en las Escuelas Nacionales, para la propagación de la geografía de la República desconocida hasta hoy (...) vengo, S. C. Constitucional a proponeros la propiedad de esta -que podría llamarse la obra de mi vida- Carta Geográfica (ANCR, 1884: 1-3). ${ }^{7}$

Sus complicaciones judiciales no desaparecieron, ${ }^{8}$ pero afectaron poco al ahora "agricultor" soltero, prestamista, denunciante de terrenos y minas en la provincia de 
Limón, y padre que dejara sus haberes en testamento a su hija Herminia Figueroa. ${ }^{9}$ De la conspiración, a los negocios; de la mirada obscena, a la mirada geográfica; el saber exploratorio se prolonga en el Álbum de Figueroa, cuya síntesis heterodoxa de contenidos hace ver a su autor como "el primero" en diversos campos: etnografía, genealogía, caricatura, arte y geografía ilustrada. ${ }^{10}$ Tal conjunción de saberes constituye una mirada biopolítica.

La antropóloga Zandra Pedraza (2004) afirma que en Latinoamérica el biopoder o gobierno de la vida, incluye expediciones de colonización interna, cartografías, conocimientos de medicina y ciencias naturales, museos de historia natural, obras de saneamiento del territorio, censos y estadísticas; el Estado actúa sobre la naturaleza (territorio, habitantes, recursos) buscando extraerla de su estado silvestre y hacerla objeto de ciencia. Por su parte, el historiador Anthony Goebel (2007) ha revelado que la correspondencia entre Alexander von Humboldt (1769-1859) y el presidente Juan Rafael Mora Porras (1849-1859) sirvió para apoyar los viajes por el país de exploradores de origen alemán; se desconoce si el exilio impidió a Figueroa formar parte de tales expediciones, pero sí se conoce de su participación en el intercambio científico entre la Iglesia católica y el Estado liberal, al acompañar las exploraciones del obispo alemán Monseñor Augusto Thiel, antes de su expulsión debido a las reformas de 1884 (Díaz, 2006).

Figueroa parece ubicarse en la transición hacia la consolidación global del conocimiento científico acelerada a lo largo del siglo XIX, proceso que, además, se inscribe en la larga duración de la metáfora de la legibilidad del mundo y de la naturaleza. El filósofo Hans Blumenberg (2000) consideraba a Humboldt, el naturalista alemán, como figura determinante en esa apropiación óptica de la naturaleza que, para registrar y cuantificar, aún no disponía de la fotografía, por tanto era la mirada inmediata del dibujo la manera de hacer inteligible el paisaje y aspirar a una panorámica totalizadora sustituta del peregrinaje. Ese procedimiento metafórico sobre la legibilidad de la naturaleza parece dar sentido al cúmulo enciclopédico, totalizador, de registros pictóricos y textuales del Álbum de Figueroa. Como afirma la historiadora del arte Gabriela Sáenz (2009), su mirada y saber constituyen un ejercicio de poder que, al nombrar (cartográfica y etnográficamente), denuncia para sí.

Con la muerte de Figueroa en 1900, el Estado adquiere y resguarda ese conocimiento sobre las formas diversas de la vida o la muerte: genealogías, crónicas de ritos fúnebres, poblaciones, ilustraciones, mapas y planos (Arroyo, 2009b; Fonseca, 2009). Tal saber era funcional para el Estado y su gubernamentalidad, en tanto estuviese vinculado a las redes científicas que el liberalismo tejía a fines de siglo. ¿Desapareció el saber ilegítimo y ofensivo en Figueroa? ¿Sustituyó la mirada patriota de lo geográfico, aquel mirar adverso a la ley? 


\section{Los cuadernos como saber sometido: el método de la abyección}

El Estado adquirió su álbum para resguardarlo y restaurarlo, pero los cuadernos de Figueroa (2010) no tuvieron la misma suerte; más que adquiridos por el Estado, fueron guardados por el gobernante, el liberal autoritario, Rafael Yglesias, en cuya biblioteca, a cargo de sus descendientes, fueron localizados y publicados por iniciativa privada (Fonseca, 2009 y 2010). Varios de sus tomos incluyen bocetos que combinaron rimas y dibujos con gobernantes y políticos en forma animal, al retratar la política nacional del último tercio del siglo XIX: el golpe de Estado de Guardia, sus funcionarios, obras públicas y actos de corrupción.

La localización casual de los cuadernos sugiere la existencia de un saber que, a diferencia del álbum, permaneció oculto. La animalidad gráfica contenida, afirma Gabriela Sáenz (2010), realiza una especie de recreación de los animales antropomorfizados de Grandville en Scenes de la vie privée et publique des animaux, publicado en París en 1842 bajo una atmósfera de censura que obligaba al enmascaramiento zoológico de la sátira política; escenario desde donde Sáenz interpreta la censura en la dictadura de Guardia. Sus disposiciones de 1872 requerían judicialmente a quien no identificara la autoría de sus argumentos, en contraposición al estímulo del uso de seudónimos en la legislación de 1824 para favorecer la actividad de prensa; ya no sería la mirada del ver-nombrar-poseer del álbum, sino "un acto de voyeurismo, una violación del espacio prohibido y el develamiento de los secretos y flaquezas del poder político, muchos de ellos nunca antes revelados" (Sáenz, 2010). La mirada ya no es totalizadora para hacer inteligible la naturaleza, sino que esta, en forma animal, sirve de metáfora para transformar en inteligible lo político.

En los bordes fronterizos del istmo, en países como México y Colombia, la sátira y la caricatura política fueron parte fundamental de las disputas entre conservadores y liberales, o entre facciones de estos para debatir la libertad de imprenta. Dibujos satíricos circularon de mano en mano desde la década de 1830; pero en la segunda parte del siglo, medios de prensa y disputas electorales retrataron la rivalidad política como zoomórfica; los límites a la libertad de imprenta y de pensamiento en el porfiriato (1876-1911), sin embargo, afectaron la producción de caricatura política, y en 1908 no quedaba un solo periódico que satirizara con ella. Estrategias de subvención y reglamentos pusieron fuera de ley a la prensa independiente y opositora, bajo el aparente manto de la constitucionalidad.11

En Costa Rica, las condiciones no eran menos limitadas, pues existieron coplas políticas desde la década de 1830 durante las disputas localistas por la capitalidad, pero por razones técnicas en la sátira de prensa escrita desde la mitad del siglo no se pudo incorporar imágenes, por lo que la primera caricatura política en prensa data de 1892 (Sánchez, 2002). Durante el régimen de Guardia, una combinación de factores limitó el desarrollo de la sátira política y, con ella, de la caricatura. En la Ley de Imprenta de 1872, 
el registro y producción de las imprentas debía ser conocido por el Estado, mientras la sátira y la caricatura eran vistas como un atentado encubierto contra el Estado, el orden público, la religión y la moral (Oficial, 1872: art. 41, 47).

Como demuestra la historiadora Patricia Vega (1996; 1999), la tecnología de la Imprenta Nacional superó la de particulares, por lo que entre 1872-1880 era la principal impresora de periódicos; no hay evidencias de censura directa, pero condiciones técnicas y legales (subvención estatal, inspección de talleres y empresas periodísticas) limitaron la labor impresa política. Además, era una época de publicaciones efímeras; la más prolongada fue El Costarricense (1873-1876), de línea oficial, y sus temáticas, a diferencia del periodo previo a 1870, eran más literarias que políticas; situación que cambió en las dos últimas décadas del siglo XIX con la creciente alfabetización, la competencia de partidos, los recursos técnicos y el uso de publicidad.

Luego de tales limitaciones, bajo las cuales Figueroa creó sus cuadernos, y en un momento decisivo para la democracia de partidos, surgen periódicos como El Gato en 1887, editado por Víctor Fernández e impreso en talleres particulares. Su encabezado ironizaba sobre los medios subvencionados; decía ser un "Periódico Político Gatuno, Liberal Subvencionado. No quiero suscripciones porque estoy subvencionado. Me he vendido, y por lo tanto, tengo el pan asegurado" (El Gato, 11 de julio de 1889a). En una especie de editorial, su autor se presentaba como

Yo, el gato, profesor de ciencias, graduado de Madures en el Liceo de Monsieur Phischenauviolet, astrónomo, agrónomo y volcánico (...) residente actualmente en la elevada casilla del barrio de Canta Ranas, y tieso que tieso como político ñeque, saludo respetuoso al público en general, y a mis colegas subvencionados en particular. Nieto del gran Misifus. Como remedando un parlamento, hablaba de la sesión de la "Ratona Grande", en "Ratópolis, donde reunidos en gran ratuna asamblea los roedores del Queso que suscribimos, nombramos nuestro Primer diente al ratón más ENTORCHADO que se pueda y acordamos que desde este momento sea él quien a todos nos ponga bozal y tire de la cuerda como quiera (El Gato, 11 de julio de 1889a).

Un artículo de la misma edición evidenciaba las inclinaciones del periódico, pues en contra del candidato liberal oficialista usaba anónimos, animalizaba el comportamiento de los actores políticos, monstrificaba falencias de la democracia liberal como la imposición de sucesores en el poder, y denunciaba abusos en la función pública:

Cansados estamos ya de ver los escritos del bando impuesto (...) misteriosas lechuzas que trabajan en las tinieblas (...) cansados de saber que dichos anonimistas son por ejemplo, dos ministros, un poeta que viene sirviendo desde la Dictadura, un literato comodin y un abogado que jamás tiene bufete (...). Y puesto que no aceptan el terreno de la caballerosidad y la franqueza, nosotros seguiremos de hoy en adelante, esgrimiendo su misma débil arma, que sólo así lucharemos con igualdad; y allá cuando el pudor, aguijoneando por las sátiras de nuestro valiente partido Constitucional, o tal vez por los regaños de su Jefe Liberal, se decidan 
a abandonar el cobarde proceder de que hoy se valen, nosotros también tendremos muchísimo placer de firmar nuestros escritos, y entonces la lucha será más hermosa (...) cada vez que ante las mismas capas pronunciamos el nombre del candidato del pueblo, don José J. Rodríguez, la alegría asoma a los semblantes (...). Perfectamente saben -y esto es lo que más entristece a ciertos gallos- que si triunfa el Partido Constitucional, que proclama al Lic. Don José J. Rodríguez, jay de las mil y una gangas que se mecen en lujosa hamaca, dentro del recinto de muchos empleadotes! ¡Ay de la prensa vendida y por ende la rastrera adulación! ;Ay de la extensa lista de militares veteranos! jAy de la tolerancia en el mal manejo de los Fondos Públicos! ¡Ay de las concesiones a los Bancos con grave perjuicio de la Hacienda! ;Ay de la monstruosa Constitución, que entre otras cosas se prestan para que los electores sean nombrados ad hoc y triunfe a despecho del país el candidato que más se amalgama al saliente Jefe Supremo! (El Gato, 11 de julio de 1889b).

Como presidente, Rodríguez no resultó tan ajeno a los liberales y sus contradicciones; luego de gobernar con autoritarismo, en 1894 le arrebató un triunfo electoral al Partido Unión Católica e impuso a su sucesor, el general Rafael Yglesias; y fue este, no menos autoritario, quien guardó los cuadernos de Figueroa en 1900. El lenguaje de El Gato se asemejaba al de los cuadernos, pero estos quedaron ocultos; como indicara sobre el caso mexicano la historiadora Fausta Gantús (2009), eran prácticas de un modelo de sociedad civil en lo público, bajo un modelo jurídico de opinión que anteponía la ley sobre la discusión.

Según la Ley de Imprenta de 1872, Figueroa estaba de nuevo fuera de regla, ${ }^{12}$ pero esta vez su trabajo creativo no llegó a manos de los tribunales, como sí, al final de su vida, a manos del presidente. Compuesto de dos colores, uno verde sobre el régimen de Guardia, y uno rojo, de crítica a funcionarios, políticos y sucesores, los cuadernos contenían algunas reflexiones sobre el método y el entorno de su sátira, sobre todo el tomo rojo; su abierta crítica al poder ("Costa Rica es singular/ todo el que llega a mandar/ logra hacerse aborrecer") (Figueroa, 2010: 4), ${ }^{13}$ tenía aspiraciones de situar una verdad frente al discurso de la ley, como un saber sometido, sepultado por la coherencia legal:

antes de pasar a ver/ esta galería inmensal de bustos en miniatural y bocetos en conserval debo advertir (...) la extraña ridiculez/ de algunas de mis tarjetas/ que son de retratos sacados/con exactitud completa/ del original mismisimo/ con sus fachas y sus fechas./ Hay también caricaturas/ similes, bocetos, pruebas,/ epigramas (...) todo veneno por dentro/ todo hermosura por fuera (...) pero no pases por alto (...) ninguna de ellas,/ que todo tiene su intringulis,/ aunque no te lo parezca, / Y pues la verdad desnuda, / en esta pícara época, / no puede ni aún asomarsel de la ley por la barrera/ sin aquella de Democles/ caiga sobre su cabeza,/ aquí vestida de invierno/ verás la verdad sincera (op. cit.: 3).

Contraponer una verdad a la ley implicaba el riesgo de caer bajo su espada y Figueroa lo corrió, pues admitió recibir información comprometedora que expuso como biografía múltiple: 
Historias a mi enviadas/ son que tengo muy guardadas; historias graves y oscuras,/ de personas encumbradas/ a las más grandes alturas.// Juntas en un libro irán,/ y dos tomos formarán/ que serán dignos de leer,/ porque allí se encontrarán/ lo que nadie piensa ver... mi libro en cuestión/ irá con buena intención/ aplaudiendo y dando palos,/ a hacer la separación/ de los buenos y los malos.// La biografía darál de todos y se mostrarál malas y buenas acciones;/ y su título será:/ Figuras y Figurones.// Es peligrosa la cosa,/ y ya veo descargar/ contra mí una turba odiosa; mas nunca me hizo temblar/ una empresa peligrosa.// Porque es muy útil y harál un servicio a mi nación/ que algún día aplaudirá,/ el libro que pronto irál a llamar vuestra atención (op. cit.: 34-35).

Tal es el estilo de su trabajo: exponer con crudeza hechos comprometedores y acompañarlos de figuras con nombres codificados bajo el disfraz bestial; una especie de biografía monstruosa e infame ${ }^{14}$ humorística y en rima. A su crítica política ("veneno por dentro"), le sumaba una aspiración estética ("hermosura por fuera"); esa doble valoración se confirma al terminar el cuaderno rojo donde, consciente de su lenguaje abyecto, también manifiesta profundos sentimientos de belleza por el acto creativo y crítico:

Despedida final,/ son mis versos tan vulgares/ y en tan vulgar consonancia,/ que revelan mi ignorancia, / mi escasa ilustración;// pero son el flevil canto/ de mis intimos dolores/y los quiero como flores/ que produce el corazón.// Cuando el alma se contrista, / saboreando los pesares, / son mis lánguidos cantares/ mi mejor consolación.// Porque en ellos vierte el alma/ toda la hiel de mi vida, / y se queda adormecida/ en tu purísima emoción.// Que el que nace condenado/ a vivir de la tristural solo goza en la amargural de su propio corazón (op. cit.: 264).

Figueroa dejó los márgenes del estigma, como "vago dibujante", para hacer negocios con el Estado como comerciante, agricultor y cartógrafo; pero la obscenidad y la conspiración no le abandonaron. En vez de amenazar con la rebelión regional y atacar el honor del cuerpo femenino, dirigió su mirada abyecta al cuerpo del político, al conspirar con evidenciar su pelaje y las sucias huellas de sus patas. La abyección, indica la semióloga y psicoanalista Julia Kristeva (2006), refiere a un polo de atracción y repulsión; lo abyecto es lo radicalmente excluido, objeto caído; sus expresiones nauseabundas y sus representaciones residuales del cuerpo contienen la violencia de un duelo por algo desde siempre perdido, que es buscado en el adentro deseable y terrorífico del cuerpo materno devorador, con el cual se identifica desde su cualidad excrementicia y asquerosa que, en la escritura, hace de la mirada un voyeurismo.

El voyeurismo de Figueroa apuntaba ahora al espacio prohibido de los secretos políticos. Su inclinación por la vulgaridad, como escritura política y composición estética abyecta, asumida con sentido existencial, se provee de cuerpos burlados, descompuestos y repuestos con partes animales; no abandonó del todo la mirada de la 
naturaleza como metáfora de un mundo legible, tampoco lo conspirativo y obsceno, sino que su método lo condensó para hacer de la conspiración una metafórica crítica monstruosa que llevaba la naturaleza (lo salvaje, lo animal) al cuerpo de lo político, del soberano.

No se conoce suficiente material biográfico para determinar el trasfondo subjetivo de la abyección; ciertamente, frente al allanamiento policial del hogar, su madre dijo desconocer los dibujos obscenos de su hijo mayor (ANCR, 1843), cuyo exilio y falta de estudios contrastaron con la noble figura del hermano menor, Eusebio Figueroa (1827-1883), quien terminó sus estudios doctorales de Derecho Civil en Nicaragua (1851) y labró una carrera de abogado en altos cargos públicos (Arias, 2011). Tampoco se conoce tensiones entre ellos; de hecho, el primero proveyó de documentos para las crónicas del segundo (Acuña, 2009), por lo cual toda hipótesis bíblica sobre Caín, Abel y su madre queda en suspenso, no así la mirada abyecta y animalista al soberano, quien tenía también sus propias metáforas.

\section{Las metáforas del soberano}

Hay una larga tradición occidental en torno a las metáforas políticas del Estado y el poder; algunas de ellas, como la nave del Estado y su capitán, u otras animales, como las del pastor y su rebaño, la tiranía del lobo, la violencia del león y la astucia del zorro, refieren a los modos de ejercicio del poder, a la resistencia, la revolución o a los vínculos entre el individuo y la comunidad, ya sea para legitimar el orden establecido o justificar su cambio, expresar emociones o denigrar al rival (Peil, 1983). En el caso del régimen de Guardia, podrá notarse que la metafórica gira en torno a las principales líneas de gobierno: orden y progreso. Estas fueron metáforas para contener una conspiración opositora enfrentada a ese liberalismo autoritario que se imponía al vulnerar sus propios principios, o para elevar las expectativas por el proyecto del ferrocarril interoceánico: metáforas orgánicas de la naturaleza o del cuerpo, a veces religiosas, pero siempre metáforas de o para el soberano.

“Regeneración" y "reorganización" fueron expresiones comunes de los golpes de Estado ocurridos en 1859, 1868 y 1870, justificados como ajustes de cuentas contra gobiernos "anómalos", y legitimados luego por autoridades locales y comunidades (Fallas, 2008); es decir, fueron experiencias de ruptura del orden con cierta aprobación democrática. De hecho, este parecía ser el lenguaje de un proceso democratizador caracterizado por reformas electorales que tendían a consolidar el sufragio universal masculino (Molina, 2009), y por el creciente interés de los grupos políticos personalistas en el proselitismo, la opinión pública en la prensa y la competencia electoral partidaria, interés reforzado por la presencia influyente de extranjeros liberales, el mayor acceso y circulación de literatura política, y el seguimiento en la prensa del curso democrático europeo y latinoamericano (Vargas, 2001). 
No obstante, este proceso fue interrumpido por los golpes militares de $1868 \mathrm{y}$ 1870. Si bien al gobierno de Jesús Jiménez (1868-1870) le cobraron las destituciones de Máximo Blanco y Lorenzo Salazar, militares protagonistas de los golpes anteriores, el de Guardia en 1870 contra Jiménez dio continuidad a la despolitización y modernización del ejército, llamando al orden en nombre de la "soberanía popular", el "imperio" y el "santuario" de la ley (Fallas, 2008). Los críticos de Guardia pronto advirtieron las contradicciones del liberalismo:

Las elecciones nacionales para una Asamblea Constituyente, que normalizara al país, han quedado indefinidamente diferidas para mejor ocasión. Tal es la soberana resolución del Supremo Consejo de Estado (...) La gran razón que presenta el Consejo, es: que la calma debe presidir todos los actos electorales $i$ actualmente se resiente en el país de la ajitación de las pasiones de partido (...) Esto piensa el Consejo; y como medio seguro de calmar las pasiones adopta la prolongación indefinida de lo que el mismo Señor Jeneral Presidente califica de dictadura; pretende consultar el orden haciendo continuar una situación anormal i tirante; aspira a conseguir la paz violentando los derechos del pueblo al desconocer su aptitud e idoneidad para ejercerlos, $i$ difiriendo su ejercicio de manera indefinida, e imponiendo a la voluntad general la de unos pocos, i con ella un sistema transitorio e irregular que no puede constituir propiamente lo que se quiere espresar con la palabra orden (...) El mismo error de los que siempre desconfían de las facultades e instintos conservadores de los pueblos; el mismo sofisma: la anormalidad conduciendo al orden; la energía de una sola voluntad omnimoda, i la fuerza robusteciéndola para reprimir todo lo que al Poderoso le parezca un mal o un delito-asegurando la paz; la dictadura produciendo la República (El comercio de Costa Rica, 1870).

Tales críticas mermaron a lo largo de la década cuando la prensa quedó bajo vigilancia del Estado, y la oposición a Guardia, en medio de una compleja recomposición de intereses y facciones (Pérez, 2013), fue limitándose al espacio de conspiración, unido aún al devenir del istmo y los intentos del gobernante guatemalteco Justo Rufino Barrios (1873-1885) por reconstruir a la fuerza la Federación Centroamericana. Invasiones y exilios involucraron a toda la región, desde el inicio hasta el fin del régimen, el cual recurrió a la disolución de la Asamblea Constituyente, al destierro, al confinamiento, a la suspensión de garantías, las detenciones, los maltratos, la intimidación y, más tarde, al fusilamiento, lo cual evidencia lo efímero de la temprana clemencia conciliadora y respetuosa de la vida (Fallas y Sequeira, 1976; Chavarría, 1982; Pérez, 2013).

Los mensajes presidenciales al Congreso reflejan tal situación política; predominan allí, al lado de la idea de progreso fija en el ferrocarril interoceánico, la preocupación frente al vaivén subversivo al interior del país en medio del frágil equilibrio político centroamericano. Tales coordenadas de orden y progreso delimitan la metafórica orgánica, familiar y religiosa del poder. Los primeros años transcurrieron entre una visión corporal y providencial del orden; Guardia recordaba cómo se puso "en una mano todo el poder social" luego de que el pueblo "buscara" y "pusiera los ojos" 
en él; bendice "a la providencia" por "haberme elegido", mientras que el ferrocarril, una especie de "motor poderoso de los elementos progresistas", sería el camino a la "civilización" y lo que daría "animación y vida y movimiento y ruido a bastas soledades habitadas por las fieras de nuestros bosques" (Meléndez, 1981a: 89). A partir de 1874, luego de intensificarse las conspiraciones, los mensajes de Guardia endurecieron el tono y su modo de gobierno frente a la "revolución" en cuarteles militares, "planes sediciosos" e "insurrección" en las provincias; Guardia afirmaba, con acento cristiano, que "lo que he hallado en la senda que recorro son espinas, que, a veces, me han herido el corazón; mas no han extraviado mis pasos" (op. cit.: 93), por lo cual exigía la "conservación del orden público", el "principio de autoridad" y la "sumisión a la ley" (op. cit.: 105-106). A pesar de haber afirmado, en 1875, que "la vida humana es inviolable", y de reafirmar una visión correctiva a través de los presidios en las islas del Pacífico, San Lucas y del Coco (op. cit.: 101), en 1877, dijo ser "inflexible y enérgico, y me impondré, si fuere necesario, hasta la abnegación y el sacrificio, haciendo a un lado los sentimientos de magnanimidad y de clemencia que me han caracterizado tantas veces, si en mi concepto así lo demandare el bien de Costa Rica" (op. cit.: 134).

La metafórica del orden permanece en la "senda de espinas", y es en 1872 cuando se reivindicaba la autoridad biopolítica del soberano que perdona y dirige la vida desde la "ciencia del buen gobierno" y desde la "ciencia militar" (op. cit.: 71-73). En 1876 aún abrigaba la esperanza de ver afianzarse la paz en la región "por medio de un pacto de unión que estrechase los vínculos de familia y que ligase a las cinco Repúblicas" (op. cit.: 107), pero dos años después mostraba precaución al usar vocablos orgánicos sobre el riesgo de "esas personalidades superiores que se denominan Confederaciones" que "llevan en sí mismas el germen de su decadencia" (op. cit.: 138). Ese lenguaje naturalista para remitir al orden de una política exterior que reafirmaba la interior, también emerge de la idea de progreso y los requerimientos económicos del ferrocarril interoceánico: "Las rentas son el cuerpo social como la sangre que lleva la vida a todo el organismo" (op. cit.: 111), por lo que había invertido en el proyecto casi tres millones de pesos hasta abril de 1876. Era una "lucha entablada contra la naturaleza, hasta que quede del uno al otro mar aprisionada por los rieles y bajo el peso de la locomotora", de hacer quedar "unidas las extremidades de ambos ramales" (op. cit.: 160-161). Ese sometimiento corporal de la naturaleza por el progreso fue retratado por Guardia con la imagen del Gobierno como viajero; pocas veces, como en su mensaje de 1878, aparece tan consciente la metafórica del dictador:

Valiéndome de una comparación ya empleada, diré que como el viajero ve cercana la cima de una montaña a donde se dirige, y al andar por las sinuosidades del camino que a ella conduce, encuentra estorbos y rodeos que le fatigan y aún le ocultan la perspectiva de aquella cima, hasta que ganando un paraje propicio, se da cuenta del esfuerzo empleado, mide lo que falta a su tarea, 
toma nuevo aliento y prosigue; así el Gobierno que presido, en la ejecución del ferrocarril que se halla en obra, ha encontrado dificultades (op. cit.: 142).

La "senda de espinas" y el "viajero" en la "cima de la montaña" son metáforas que resumen el lenguaje del dictador, inteligibles bajo los significantes del orden (contener la conspiración) y el progreso (el ferrocarril). Su clemencia ubica la conspiración en un registro exterior, pues a sus habitantes los distingue por su "moralidad", "pacifismo" y carácter "laborioso"; la "Providencia" dispensa "el beneficio inestimable de la paz y la tranquilidad interior" (op. cit.: 95) a esa "población homogénea, compuesta de propietarios en mayor o menor escala" (op. cit.: 134), quienes no debían contagiarse del "germen" de la "decadencia" regional.

El eco de sus palabras repetía la condición de elegido. El periódico oficialista El Pueblo defendía en 1878 al Gobierno frente a la invasión de Federico Mora, ${ }^{15}$ a cuyos integrantes trataba de "revoltosos con pretensiones de ser Gobierno de Costa Rica", "reos rematados, conmutados unos i prófugos otros, de penas corporales o infamantes", y mostraba sorpresa por la "complicidad del Gobierno Nicaragüense" (El Pueblo, 1878). Aunque este negó su participación, el articulista distanciaba el destino costarricense respecto a la región con una metáfora animal: "el día que tengamos que buscar alianza, lo haremos por el lado del Sur, a donde hace tiempo ya no existen Panteras, i hai decencia" (loc. cit.). Ese recurso zoológico no parece haber sido común en la prensa de la época, ante el predominio de una metafórica donde Guardia era capitán de una nave. El mismo periódico utilizó esa imagen jerárquica donde, para salir del peligro y la tempestad, se requiere del capitán al que los marineros obedecen a voluntad, a costa de sus propias vidas y de la comunidad (Peil, 1983); el peligro era Centroamérica y la tempestad unionista de Rufino Barrios:

El 1878 se nos presenta con una perspectiva nada favorable; nos asoma su horizonte empañado; en lontananza nos muestra esa nubecilla, que aunque parece de poca significación, mui bien puede ser como la precursora de esas borrascas que se desencadenan en el Mar, para contrariar las cuales i evitar el naufragio de la Nave, el Piloto tiene necesidad de recoger en sí mismo todo su talento, experiencia i energía, comunicarla a los tripulantes, i permanecer por todo el tiempo preciso en guardia, sin desatender ni la driza que parezca más insignificante. La tempestad que nos anuncia el barómetro político, es la guerra de conquista con que nos amenaza el General Don Rufino Barrios, Presidente de Guatemala, que cual una Avalancha i ridicula parodia de Atila, quiere con sus Hunos de nuevo cuño arrasar con Costa Rica./ Pero nuestra Nave tiene por Piloto al General Don Tomás Guardia, i por tripulantes a todos los Costarricenses, que atentos a la menor señal de mando, con la mayor presteza cumpliremos nuestro deber (El Pueblo, 1878).

A la muerte de Guardia, su sucesor Próspero Fernández (1882-1885) elevó al dictador a una altura providencial, como héroe de la regeneración y la salvación: 
Desde la Mansión Eterna, a donde pasan de esta vida temporal las almas purificadas, desciende una voz que os bendice. Es la del héroe que tanto anheló la regeneración política de su Patria; es la del Dictador que os convocó a este recinto, y cuya voluntad abnegada está cumpliéndose, a la par del destino justo y preciso de esa Patria que tanto amó (Meléndez, 1981a: 167).

Aquella metafórica del orden y el progreso tuvo sus profanaciones. El presidente Fernández reafirmaba la "gloria de empezar esa transformación", la "regeneración a la que todos aspiramos"; pero le inquietaba "la posibilidad, que ojalá no sea más que un fantasma, de que hay quienes pretendan detener al Gobierno en su marcha regeneradora" (op. cit.: 171). Tras la regeneración estaba la abyección; como el temido fantasma, Figueroa revelará una nave con tripulantes amotinados y roedores, donde el héroe era un monstruo.

\section{Animalidad e infamia: las bestias devoran al cuerpo estatal}

La zoología política configura lo humano y el poder desde la animalidad, una mezcla con deformaciones monstruosas (von der Heiden y Vogl, 2007); categorías metafóricas del pensamiento político como la bestia y el soberano propuestas por Derrida (2010) sirven para atender los como si de la historia, además son fabulaciones de la acción y el discurso político destinadas a enseñar desde lo animal y la metáfora, donde lo histórico sucede y se registra, pero a la vez se significa como si. La soberanía es instauración, obediencia y conservación de la ley, pero el soberano y la bestia tienen en común el estar fuera o por encima de ella; su desacato los asemeja al criminal, ejercen un saber soberano distinto del saber sometido. Con Figueroa, la metafórica o fabulación animal, el como si del régimen de Guardia, configuró un saber crítico opuesto a las metáforas del soberano y su ley.

El cuaderno verde de Figueroa inicia refiriéndose al golpe de Estado de Guardia el 27 de abril de 1870, y traza una composición animal del arribo al poder y su ejercicio. Los recursos metafóricos son diversos; la animalidad no parece inspirarse estrictamente en la fauna local que Figueroa conociera en sus expediciones (Goebel, 2011); varias de las especies que sirven a la ofensa política encuentran asidero en una larga tradición simbólica de las metáforas animales del poder. Los insultos son muchos, los cuerpos animales también; generalmente los nombres aparecen en clave o quedan atrapados en juegos de palabras, pero el objetivo de este artículo no es descifrar por completo la identidad política, sino valorar el saber crítico de la metafórica política animal frente al saber soberano y el lenguaje del poder.

Los golpistas de 1870, más que héroes regeneradores, eran una "rapiña vergonzosa", cada integrante del nuevo Gobierno tenía cuerpo animal: aves terrestres, reptiles, roedores, entre otros. (Figueroa, 2010):16 "la omnipotente y tufosa trinidad Chompipezca (...) fue en esa época cuando apareció la monstruosa, y Soberana 
Convención Nacional la mayor parte de ella compuesta de diputados víboras extremadamente ponzoñosas que devoraron al país y lo mutilaron" (op. cit.: 3-4). El soberano era asociado con lo criminal mediante la escatología del método de la abyección:

Dedicado a Dn. Chiva Cagada de moqui-/verde/. Epigrama/. Cierto empleado petulante/ que mal trabaja y bien ganal Me dijo cierta mañana/ con el aire de farsante/ Es ingrato mi destino/ esto de pensar, y luego/ escribir tan sin sosiego/ Es trabajo de pollinol (...). Dicen el destino mucial El vil fiscal de moqui manga/ (...) como este sucio animal/ El Comandante Dn. Candelas/ Que gente tan criminal/ A mí me importa un anís/ el fluido tan asqueroso/ de este sistema mucoso/ que sale de mi nariz ./ Yo gasto bigote espeso/Que se esponja ese bigote/ y cara de monigote (...). Lobo, chiva cagada a la vez/ Puerco de negros parches lleno/ Allador y chismoso ameno/ Y gran notable al rebez/ Que por falta de aduladores/colócanse malhechores/La cuaterna de bribones/ que para ponerse calzones/ sacrifican a los señores/ de Cartago y sus rincones" (op. cit.: 12).

El poder irrumpía y se exhibía, por lo que Figueroa recreó escenas vinculadas a los proyectos de progreso del régimen, como las negociaciones de préstamos en Europa para el ferrocarril interoceánico; además criticaba su costo oneroso y las complicaciones del erario. Guardia aparecía como zorro vestido de militar, animal identificado con la astucia en la tradición política occidental ("el GG con su hija la graciosa morena la angelical Angélica exhibiéndose en Europa" (op. cit.: 55)), pero justo al embarcarse en el puerto de Puntarenas para hacer su viaje a Europa, la metamorfosis lo mostraba como un ave de instintos rapaces:

El General Guardia con su comitiva llegan a Puntarenas, a embarcarse para Europa (...) [Un acompañante dice]... En el aviso me creí hundido/ y en la mar a lo pijijel ;O Señor General! le dije,l-iUsted también está arrepentido?/ Mi General respondió/ No te aflijas mi Pablito/ pues ni en el conflicto/ dejo mi rapiña Yó (op. cit.: 62-63).

Figueroa muestra al ave Guardia paseándose con "su séquito en las calles de Londres", un grupo de elefantes, perros, monos, lagartos y demás, o en un "banquete dado en obsequio" al General "por los especuladores del empréstito en la ciudad de Londres". Luego aparece "con su comitiva exhibiéndose en la ciudad de París, pa dar honor e importancia a Costa Rica" (op. cit.: 67-68), ciudad de donde provenían algunos de los capitalistas mediadores en los préstamos para el ferrocarril. Los presidentes, bajo la sombra de Guardia, compartieron su destino zoológico. En vísperas de la elección de Aniceto Esquivel (1876), Figueroa dice que "Con la elección de Presidente/ del hipopótamo ursulino/ es muy grande el desatino/ en que está toda la gente,/ con Cándido agua caliente/ en paño el serote envuelto" (op. cit.: 78), "mientras aparece el ave rapaz rodeado de su séquito animal, engullendo un ferrocarril" (op. cit.: 73); al momento de la toma de posesión, el ave coloca un bozal al hipopótamo "Aniceto 
Ursulino" (op. cit:: 79-80), clara alusión a las condiciones de traspaso del poder; pues en menos de tres meses fue depuesto por un golpe de Estado. Saturnino Lizano (1882), quien sucedió brevemente a Guardia al morir, apareció en los cuadernos bajo el mote de "Saturnio Lizano", un "Calamuco animal/ con pretensiones de Mariscal/ y sin táctica ni precaución,/ se llevará el diablo la nación" (op. cit.: 77).

\section{METÁFORAS DE LA ANIMALIDAD EN TORNO AL PROGRESO Y A LA SUCESIÓN DEL PODER}

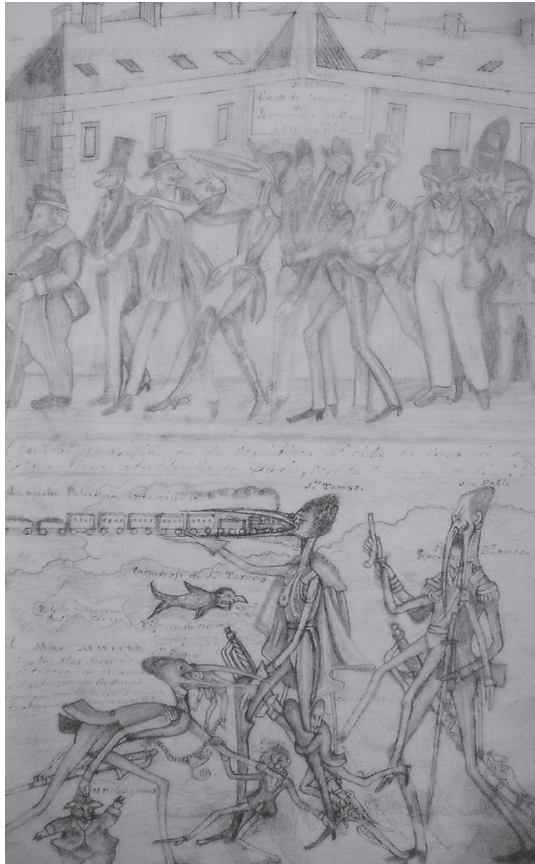

El "ave" Guardia engulle al ferrocarril frente a su séquito animal

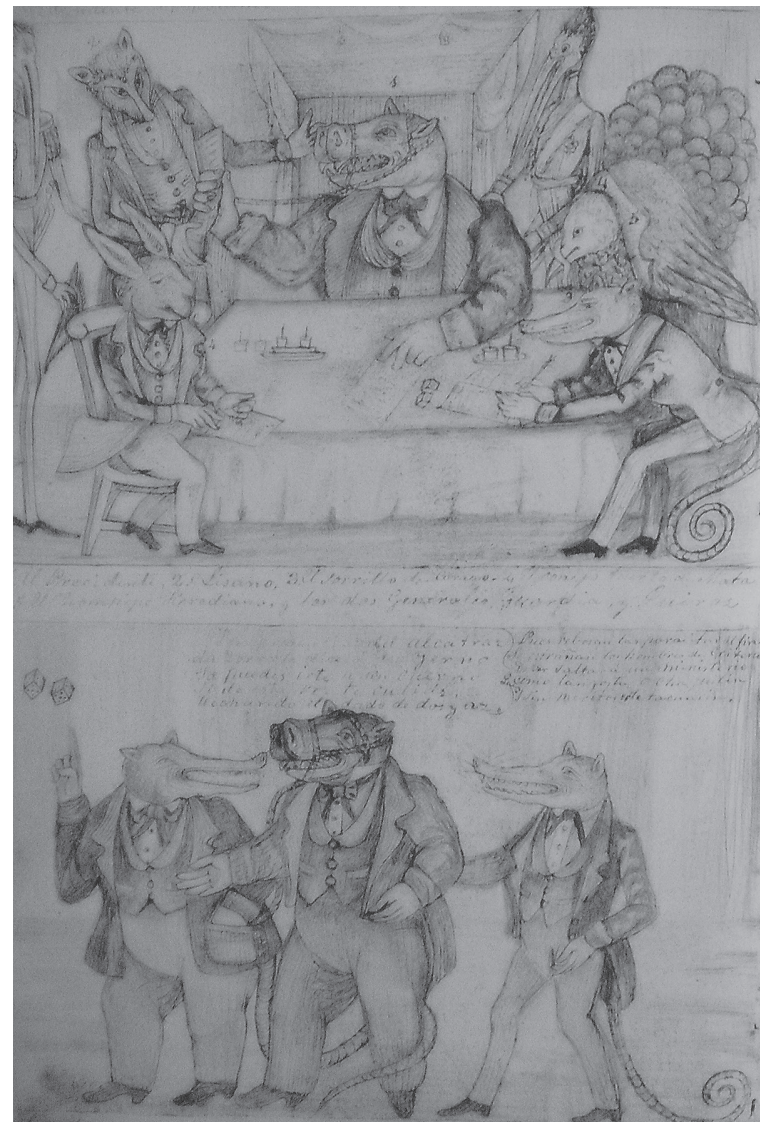

El "ave" Guardia coloca el bozal a su sucesor, el "hipopótamo" Aniceto Esquivel

Fuente: Figueroa, 2010: 87, 94.

Dicha situación hacía que Figueroa viera a su país como "corrupto e infecundo", "infame" e "infernal" (op. cit.: 78, 81), de lo que culpaba a la dictadura y a las "sanguijuelas" que vivían de ella: "Recuerdo de amargura/ en su infame historia/ 
Recuerda en su memoria/ Costa Rica tu dictadura" (op. cit.: 76). Una vaca agonizante o un cuerpo muerto metaforizaban la nación, pronta a ser devorada por los funcionarios del régimen, unos "animales desenfrenados" y

traidores de profesión/ de rapiña tan audaz/ que por delante y por detrás/ destruyen la nación./ Robándola sin cesar/ y mal gastando el erario/ los sátrapas del sicario/ pa sus rentas disipar (...) Para engañar al pobre país/ que la desgracia ha tenido/ que se le hayan introducido/ gorgojos al maiz./ Langosta, polilla y zompopos./ Cucarachas, chapulines o pulgones./ Jobotos, ratas y ratones./ Ardillas mapa chinches y Topos/ y cuanta sabandija es dable/ a devorar su país natal./ De ponzoña insoportable./ O Tabanera tan fecundal Sanguijuelas para chupar/ la sangre se han de cuipinar/ de su patria moribunda/ y como vampiro insaciable/ que chupa de noche y no de dial la parranda y botarateríal con desparpajo admirable/ caen sobre el erario con tezón/ como loros, chocoyos y pericos./ $Y$ hasta los negros congos y micos/ de la hacienda llevan su ración (...) A saquear todos los puertos/ a esto quedará reducido/ el partido liberal/ usurpándose el capital/ de su país bien adormecido./ Comparado el país con una vacal parida, y leche muy abundantel escurrida la dejaron y tirante/ al extranjero la llevaran en Sacal pero antes creo que se muere de flaca.// Colgante el pobre país en tasajeral no sé si de mortandad o matanzal devorados los intestinos y la panzal han dejado la vaca en la hueseral toda esta infame zopilotera (...) Qué bien se paga lal adulación (...). Murió ya un empleado/ presupuestivo audaz/ que harto ya de haber mamado/ murió el pobre desolado/ por no poder mamar más (op. cit.: 71-72).

Los seguidores del dictador debían estar agradecidos; "mientras V.E. permanezca en el mando los nuestros tendrán un pan que comer a costa de la desgraciada nación" (op. cit.: 83). Los mecanismos de cooptación de la dictadura eran muchos (Pérez, 2013); Figueroa fue impecable con esos "reptiles" al referir a Julián Volio (1827-1889), abogado y educador con distintos cargos públicos, entre ellos el de ministro de Gobernación:

al inmortal Volio (...) al inmortal espectro resucitado/ Pico y uñas de halcón/ y en sus miradas lechuza/ hombre de ciencia infusa/ abogado de profesión/ especulador literato/ escuálido y entecado/ muerto resucitado/ y que padece de flato/ raquitico en su figural serpiente muy venenosal con astucias de raposal y tarasca de cornudal politico de regolinal financiero en tu bolsillo/ diplomático hormiguillo/ instrumento de vaginal lobo voraz y carnicero/ horrendo ponzoñoso escorpión/ pálido cutis de condón/ como alacrán rastrero./Vampiro en tus acciones/ Devil pero temerario/ se engulló todo el erario/del país sin condiciones/ Eslabón de una cadena de cómplices criminales politicos e infernales/ a quienes el país condena (...) eres insaciable hambriento/ precisa tu destrucción/ hombre sin fe ni ley/vitalicio en la maldad/ no tienen seguridad/ ni los mismos de tu grey./ Litigante temerario/ Ministro y gran masón/ para tu casa gran ladro [¿ladrón?]/ Acarreaste con el erario/ a vos Julianesca Honorabilidad (Figueroa, 2010: 84).

La nación era un cuerpo enfermo que, para ser curado, requería se le extirpara ese devorador desobediente de su propia ley. Derrida (2010) relacionaba el poder del soberano con el de la bestia desde esa ley que establecen sin respetarla, granujas que 
no siguen la ley de la manada, como un "Estado canalla" que irrespeta el derecho a la guerra. Figueroa recrea tales categorías al desear arrancar al "canalla" del país enfermo:

mi gobierno es una plagal Con nuestro país acabal como enfermedad endémical o epidemia mejor dicho./ jSi generales como yo soy/ no toman el poder hoy/ acabaremos como un bicho./ cáncer en el intestino cardial y en un estado inflamado/ no puede estar más infestado/ que la administración Guardia./ Un plan voy a formar,/ estratégico y de batallal pa quitar a este canallal y poderlo despichar (Figueroa, 2010: 65).

Su lenguaje conspirativo confrontaba el simbolismo fálico de la espada militar (Münkler, 1994), justamente un sector predominante en el régimen de Guardia (Pérez, 2013). Figueroa invierte la metafórica del capitán o del héroe regenerador, y recuerda con repugnancia el poder militar desde sus símbolos y conmemoraciones:

los hijos de la patria solo cantan/ las páginas doradas de su historia;/ de sus heroicos próceres la gloria...[los] gritos de esa turba miserable,/ cuando en burla sangrienta y mal nacida,/ se mofan de la patria doloridal y al mirarla en abismo inmensurable,/ cantan el triunfo del nefando sable (Figueroa, 2010: 90).

El cuaderno rojo inicia con la muerte de Guardia; su sucesor, Próspero Fernández, elevó a los cielos al héroe regenerador, y Figueroa opuso a lo divino lo infernal, dejando en llamas la muerte del general. Sin haber podido quitar al "canalla", lo despide con burla:

Que si le pica que rasque./ Próspero./ A todo trance hay que hacer/ ahorros por más que cueste./ Con otro golpe como estel me eternizo en el poder (...) La capilla ardiente del egregio general Guardia en la Catedral de San José. Discurso del Gran Canciller (...) Programa de liberal, y humildad de pretendiente (...) como se vienen se van (Figueroa, 2010: 2). ${ }^{17}$

A la muerte del dictador, Figueroa se concentra en sus funcionarios, cuyas historias de infamia consignan la corrupción del régimen. El recurso de la infamia como monstrificación fue utilizado también en Chile por historiadores liberales que opusieron la historia infame de personajes malditos para la patria a la consagración de un panteón de héroes (Vicuña, 2008). Según Foucault (1996), la historia de infamia crea un "monstruo de abominación" a partir del recuerdo ominoso y el respetuoso terror que dejan ciertos personajes; no es un texto literario de lo fabuloso, sino la narración de lo ordinario, lo oculto que obliga a lo cotidiano a salir a la luz y decir lo indecible, secreto e intolerable. Además, en el Código Civil de 1841 la infamia era una pena no corporal equivalente al retiro de la nacionalidad (Oficial, 1858), por tanto lo de Figueroa no deja de ser un ajusticiamiento al soberano que corrompe su ley. 
Desde la estética de su método abyecto, transgrede la incipiente historiografía patriótica y profana su panteón de héroes; de estos dice lo innombrable y ajusta cuentas donde nadie parece rendirlas. Contratos "onerosos para el fisco", "otros que no han querido rendir cuenta del dinero guardado en su poder como tesoreros", "empleados que no cumplen el juramento que han prestado", "fraudes y usurpaciones de miedo porque el fraudulento pertenece a una familia numerosa de parásitos que siempre están arriba" (Figueroa, 2010: 14). El saber crítico saca a flote una verdad más allá del dictador:

Mi vigilancia, como debe ser la del que manda, se ejercerá constantemente contra los vicios. Esta vigilancia nace sobre todo del odio, y repugnancia con que los miro (...) he sido indulgente para no tener que castigar con demasiado rigor, a mis colegas, y amigos! Pero iJugadores en politica y demás viciosos! No conteis ya más con mi indulgencia. El Sor. Comandante de esta plaza que es un hombre probo, está encargado de impedir los abusos de autoridad, los asesinatos por jefes militares en las plazas de toros, y calles públicas (...) recibir pago de estos por licencias para ausentarse por horas, o por dias; robando así a la nación el servicio de estos, el mal ejemplo y falta de subordinación que cunde en el ejército; las detenciones arbitrarias (...) arrestos inmotivados, y contrariedad de fueros de que algunos empleados militares negocien con las rentas públicas, y en trabajos públicos (op. cit.: 15).

La animalidad sigue presente, pero dentro de la historia de infamia se convierte en biografía de monstruos. Ironizando el asomo democrático ("pongo humildemente mis efímeras estrofas a vuestros democráticos y hediondos pies" (op. cit.: 17)". Figueroa evidencia en detalle el caso de Manuel Marchena, un funcionario de la Casa de la Moneda dibujado con cuernos, alas y garras, mientras acuña monedas; trazando su monstruosa genealogía, lo une de modo infame, abyecto y zoológico con el pasado golpista militar:

Un empleado, aborto del 27 de abril del año 1870, tipo de la mayoría de los empleados de aquella fecha (...) ¿Quién será? Es un criollo servil/ Petardista, infame mordaz/ Sollastre, sucio, incapaz/ Vago, indecente muy vil.// Pues,/S Su nombre termina en _el/Y su apellido en_enal Tiene corazón de hiena/ Y como el tigre es cruel// Su mirada es de pantera/ Sus halagos de cocodrilo/ Cuando hace presa en el Nilo/ Como acostumbra esa fieral/ Es calumniante, y embustero/ Fatuo, presumido, y bobo/ Tiene instintos de lobo/ Y como culebra rastrero (...)// Es tonto, engreído, pendejo/ Falsario, aleve, ladrón,/ Y cochino en su manejo/ Como lo es todo bribón//(...) Yo te rindo el homenaje/ Que merezcas lector mio/ Si adivinas sin desvio/ Quien es el personaje/ Que describo (op. cit.: 23).

Sin dar tiempo a adivinar, anuncia la "Vida del aventurero Manuel Marnache", e invierte las últimas sílabas del apellido. Figueroa, antiguo "vago mal entretenido", adopta el lenguaje del poder para devolverle la acusación. "Marnache" es un "vago mal entretenido", un "gran pillo malhechor", de yanquis "envenenador", "vil ladronaso", "falsificador a mano" y de "conducta criminal" (op. cit.: 24). Figueroa le atribuía causas 
criminales como falsificación de moneda, sellos, cartas y documentos, así como fraude con fondos públicos, estafas, soborno, cohecho, prevaricato, robo y vagancia; atrapado en el puerto de Moín, Marchena escaparía dejando tras de sí envenenamientos mortales al hacerse pasar por curandero (op. cit.: 35-37). El lenguaje de la infamia emerge entre fraudes: "no pudo sacar nada de sus infamias" (op. cit.: 45), "Se le viene a la memoria la infamia que hace con su misma madre de falsificarle en un poder fingido" (op. cit.: 51), y "También recuerda el infame la que hizo con su compadre" (op. cit.: 53).

Cargos por falsificación de moneda aparecen en decenas de folios judiciales desde la década de 1860; pero el caso de Marchena se inscribe en esa serie de funcionarios premiados por la dictadura, cuyos mecanismos de represión selectiva en medio de la conspiración política privilegiaron a algunos con la impunidad para no perder su lealtad y contener la subversión (Pérez, 2013). Testigos interrogados confirmaron las pillerías del infame:

haberse escapado de un asesinato que ivan a perpetrar en él los Sres. D. Manuel Antillón y D. Manuel Marchena (...) y fue que sirviendo el que declara al Señor Marchena descubrió el negocio de la manera que los mencionados falsificaban, en la Antigua Villa de Ujarrás, y estando el que habla en dicho sitio, lo condujeron a un bosque en donde le trasaron un hoyo que debia abrir y teniendo como media vara de hondo, y el Señor Antillón lo tomó de la mano, y habiéndose escapado le dio un tiro y como no se lo pegó, porque era entre oscuro y claro, pues serían las seis y media de la noche, no le hizo nada con el tiro: que entonces tomando un camino destraviado se vino para la Villa del Paraízo (...) permaneció toda esa noche alli: que otro día se vino para su casa en donde estuvo pocos días, y temiendo las amenazas, y la muerte que querían darle los Sres. Antillón y Marchena se fue para Matina en donde ha permanecido, sin embargo que Don Manuel Marchena fue hasta Moín en su busca y como él se ocultara, le ofrecía que se fuera con él (ANCR, febrero-julio de 1860).

El vínculo del funcionario con la dictadura sirve a Figueroa para construir una metafórica monstruosa desde el lenguaje de abyección; al tratarse de un aborto, residuo materno, el autor reconstruye la imagen de un mal nacimiento del cual surge el monstruo deforme, prefigurando las metáforas biopolíticas que más tarde poblaron el discurso político y sus confluencias con el saber médico (Arias, 2013); Marchena era un "monstruo abortado" que fue "nombrado por el Gobierno revolucionario del 27 de abril" (Figueroa, 2010: 43).

En otra biografía infame, dedicada a Mariano Montealegre (1816-1900), la operación es distinta; ya no es la expulsión monstruosa en el nacimiento, sino la introducción abyecta del monstruo en los orificios excrementales del cuerpo. Los Montealegre eran una familia ligada a la economía cafetalera; ellos participaron del golpe de 1870 que, inesperadamente, limitó su influencia política y militar (Cóver, 1982). La infamia del personaje radica en sus redes de parentesco y negocios con otras familias oligárquicas, en el privilegio de ser parte de la conspiración contra la dictadura y quedar impune 
por la cooptación selectiva de Guardia (Pérez, 2013). Figueroa trata a Montealegre de "bribón" y "ladrón", e incluye lo abyecto al decir que a Mariano "yo me lo meto en el ano (...) Al Estado nada trajo,/ y es un sucio pordiosero:/ me lo meto en el trasero./ para que salga cagado" (Figueroa, 2010: 63). Poco después refiere a él como animal mezclado, monstruo de alta alcurnia pero no ajeno a la bestialidad:

un búfalo comparsa (...) un rico bufón (...) en sus costumbres es incestuoso/ en sus negocios, solemne bribón.// Es rico, usurero, ignorante, soez/ en política mucha importancia se dal Intrigante, feo de cabeza a los pies/ monstruo que jamás se ha visto ni verá.// De burro su corchete tiene las orejas/ gran animalazo que no le va en zagal la pica de docto el enorme zoquete,l de sus bestialidades solo se paga (op. cit.: 68).

Personajes como estos integraban la creciente burocracia estatal. Parte del cuaderno rojo alude al costo fiscal de la corrupción de los infames funcionarios, temor no salido de la ferviente imaginación de Figueroa. El historiador David Díaz recuerda que "solamente de 1875 a 1881 los empleados públicos aumentaron de 1683 a 2118, hasta llegar en 1882, a 2310 la planilla de burócratas" (2005: 46). En el universo zoomórfico de Figueroa, el Estado tiene cuerpo famélico gracias a los "amantes del presupuesto" (Figueroa, 2010: 95, 163), a la "empleomanía" (op. cit.: 176); ofrecía "empleos y blasones", "carteras", "gangas y buena colocación". En "mí Costa Rica enflaquece,/ en mí la deuda se aumenta/ y árida, mustia y sedienta/ descubro la hacienda al fin" (op. cit.: 74). "Si yo fuera Presidente", anotaba, "Mueran las constituciones!/ Solo vivan los placeres" (op. cit.: 99-100). Al denunciar la corrupción estatal, profanaba el panteón heroico de la dictadura como si fuera un cementerio de notables animales:

Entra [a] cualquier cementerio/ y según los epitafios,/ cada sepultura encierra/ un virtuoso ciudadano./ Todos los que alli reposan// fueron en vida unos santos,/ y yo absorto me pregunto:/ ¿Dónde entierran a los malos? (...) Aqui duerme un prestamista, / generoso, y tan atento,/ que siempre tuvo a la vistal la ley del ciento por ciento (...) Panteón de notables/ Epitafios de esta ciudad (...) Aquí descansa un Ministro,/ que hizo una fortuna loca;/ no hizo la de su Nación,l pero supo hacer la propia./ En la paz de este sepulcro,/ descansa un clérigo animal,/ de un atracón exabrupto./ Un letrado aquí reposal que tuvo tan mala suerte,/ que a todo el que defendió,/ lo condenaron a muerte./ Aquí descansa un doctor,/ que se murió sofocado,/ por no haber nunca curado,/ el más minimo dolor (...)/ Reposa aquí un empleado/ presupuestivoro audaz/ que harto ya de haber mamado,/ murió el pobre desolado,/ por no poder mamar más (op. cit.: 86-87).

Los mensajes al Congreso del presidente Fernández y de su sucesor, el general Bernardo Soto (1885-1889), confirman los problemas de las finanzas públicas y la necesidad de corregirlas sin suprimir los empleos, las obras públicas y la negociación de la deuda externa legada por el ferrocarril interoceánico (Meléndez, 1981a). En 1886, Soto trazaba con metáforas orgánicas una posible reforma tributaria: 
toda reforma rentística, aun cuando se establezca sabia y oportunamente necesita pasar, como toda creación nueva, por cierto período, que podríamos llamar de infancia, durante el cual se verifica su desarrollo con el concurso de hechos accesorios que suplen a lo imprevisto; y entre tanto que tales reformas llegan a la madurez, no hay que esperar de ellas fruto positivo que satisfaga a los fines de su establecimiento (Meléndez, 1981b: 34).

Sin embargo, esta era la metafórica orgánica del poder, no la de Figueroa y su cuerpo estatal famélico devorado por infames bestias. Su dibujo de una Estatua de la Libertad de Costa Rica es escéptico del orden y el progreso; la mano en el escudo parece referir al lenguaje obsceno de "meterse por el ano" al poder infame. La estatua está rodeada por un rebaño y custodiada por un soldado con tres caras que sugieren movimiento y vigilancia; el texto abyecto reafirma la succión del Estado:

¡Oh adorada pillería!/ Yo te ofrezco en este dial Mamadas y contribución/ dadme una colocación/ mientras chupo, Vida mía (...) Deja el pueblo por fin de/ ser rebaño/ el hombre al fin es hombre (...) con las arcas del tesoro/ viven bañándose en oro/ y ultrajando a la Nación,l que los llamo con razón/ ladrones de capa de oro (Figueroa, 2010: 110).

\section{METÁFORAS ABYECTAS Y ANIMALES DEL ORDEN Y DEL PROGRESO BAJO EL MANDO MILITAR}

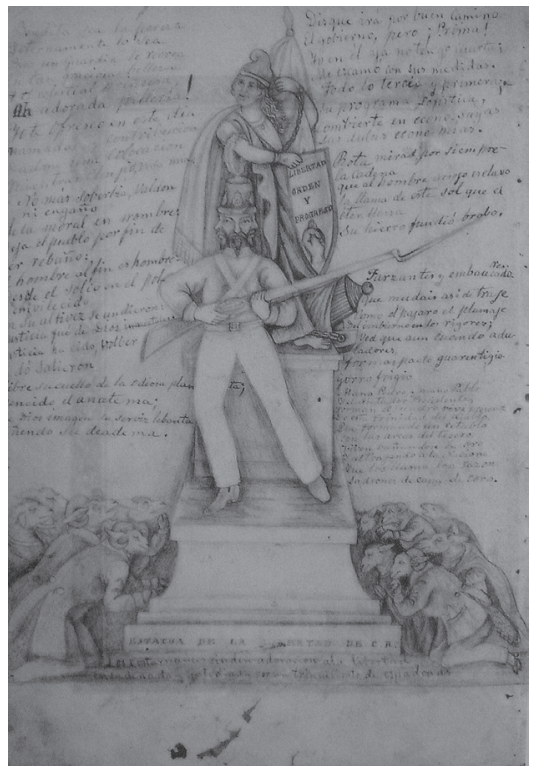

La estatua de la libertad, el orden y el progreso; la mano obscena y el soldado vigilante del rebaño

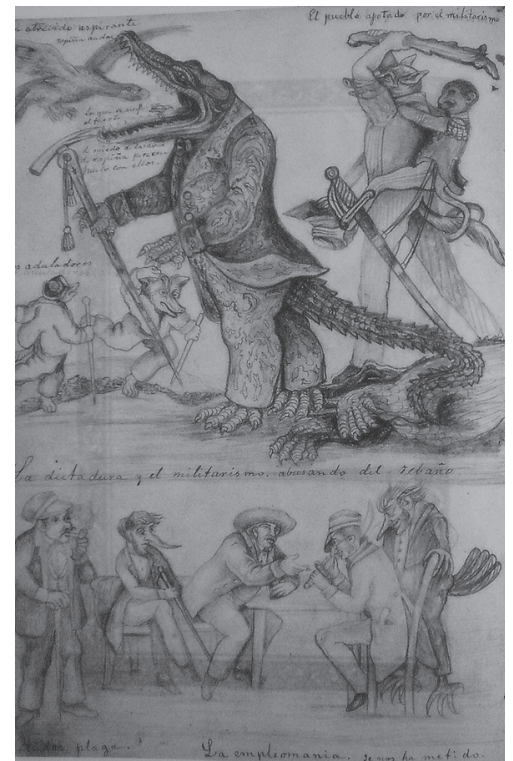

Animales militares con su espada, en posición de devoración del rebaño

Fuente: Figueroa, 2010: 300, 368. 
El texto que acompañaba la imagen de la estatua ("Los costarricenses rinden adoración a la libertad./ Encadenada y custodiada por un triunvirato de espadonas") sugería la continuidad del poder militar una vez acabada la dictadura, usando nuevamente el simbolismo fálico de la espada. La figura 4 muestra un lagarto y un mono, identificables como militares por su uniforme y espada, en postura de devoración y abuso del rebaño; los textos ayudan a interpretar la imagen: "Un atrevido aspirante/ rapiña audaz/ el pueblo azotado por el militarismo (...) Los aduladores/ La dictadura y el militarismo, abusando del rebaño" (op. cit.: 176). La espada también es motivo central del texto:

para limpiar de tu estancia,/ el inmundo estiercolero/ necesita un siglo entero (...) tú has hecho tu retrato en tu correo:/ caricatura ruin, engendro feo,/ aborto abominable de Luzbel./ Tu espada, viejo audaz, no tiene filo,/ Y si lo tiene, hiérete a ti mismo,/ Tú defiendes el cacatolicismo,/ mas no el catolicismo, viejo infiel! (...) El general de Sainete,/ a quien no causa rubor/ Vender espada y honor/ al que más paga promete;/ que del arte militar/ no tiene idea siquiera; por más que negarlo quieral es general Calamar (op. cit.: 183).

La metáfora del pastor y su rebaño, indica el historiador Dietmar Peil (1983), fue utilizada en Europa durante la Antigüedad y la Edad Media; refería a las relaciones políticas del absolutismo y la verticalidad entre el monarca y sus súbditos, pero perdió vigencia con el desarrollo de la teoría política, las relaciones contractuales y, a partir de la Revolución francesa, adquirió una connotación negativa que la llevó del texto político al humorístico. Justamente es esta la operación que realiza Figueroa para denunciar el autoritarismo militar, la corrupción estatal, la memoria y el lenguaje de la dictadura liberal y sus herederos. En la tradición de la metáfora pastoral, el analista cultural Thomas Macho (2007) recuerda que hay buenos y malos pastores: los que cuidan su rebaño y los que permiten sea devorado. En un momento de crecientes tensiones entre liberales y católicos, Figueroa parece sugerir que ni el liberalismo ni el "caca-tolicismo" cuidan su grey.

\section{Epílogo del "monstruo nefando"}

Era 1885 y otro gobernante fallecía: “Próspero se fue/ a la eternidad/ Estaba del poder harto/ Porque supo y es verdad/ que en la caja no hay un cuarto!/ partido por la mitad" (Figueroa, 2010: 264). La tapa posterior de su cuaderno rojo decía: "La momia costarricense. Muerte de la benemérita asnal borrachesca. Monstruo nefando de la patria mía". Lo nefando es lo que no puede dejar de verse sin repugnancia y horror, esa secuencia animal del orden y del progreso que dejó al Estado mal habido: "Próspero el país acabó// Junto con su execrable existencia/ el erario en miserable indigencia/ todo en la patria lo hundió (...) Jesús te ayude con un buen trago// El asno muerto/ la cebada al rabo// no más borrachones/ ni pillos no más;/ se fueron los bribones/ jamás volverán". 
Figueroa era consciente de sus metáforas, pues decía que "Hablando con maestría/ de las formas de gobierno,/ un fabulista moderno/ defiende la monarquía/ rasgos muy originales/ tiene el ingenioso autor;/ pero ninguno mejor/ que ponerla entre animales" (Figueroa, 2010: 175). Optó por una metafórica monárquica para evidenciar la contradicción autoritaria del liberalismo y sus principios republicanos; sus opciones políticas metaforizaron la dictadura con el lenguaje de lo despótico: “Ya el tirano va a expirar/ el pueblo ruge y se irrita,/ y hay bombas de dinamita/ para que sucumba el Czar./ Ya nueva era va a empezar,/ pues la esclavitud mancilla./ No doblará la rodilla/ ante el rey el Jornalero" (op. cit.: 93). Lo que la historiografía contemporánea, con su visión de largo plazo, atribuye a la dictadura (premisa del Estado moderno y la democracia), Figueroa lo experimenta desde la inmediatez y la incertidumbre de futuro, cuando el fin de una era militar deviene en el inicio de otra y se restringe la deliberación pública al saber oculto de la zoología política, expresaba "caiga el arte, la ciencia,/ que el genio se enerve y muera/ y que sea una quimera/ la libertad de Conciencia" (op. cit.: 92).

Al recoger sus tempranas experiencias con la ley, contrapuso un lenguaje al discurso del orden, el progreso y sus héroes. Sus expedientes de obscenidad y conspiración, y su saber naturalista fueron redirigidos a un método, visto aquí como abyecto, para hacer lectura animal y monstruosa de la política. Compartió con el poder un saber biopolítico, gubernamental; incluso reprodujo las nociones orgánicas del Estado como un cuerpo. Sin embargo, su metafórica no era la del soberano; a las metáforas del orden que, según Münkler (1994), alertan de la omnipresencia del peligro, de la necesidad de la vigilancia permanente, de la confianza en el líder, de la pasividad frente al Gobierno y de la seguridad sin libertad, Figueroa contrapuso una metafórica para problematizar -en palabras de Peil (1983)- lo desalmado en la política, cuestionar el poder y la vulnerabilidad de la propia ley.

Allí entran en fricción el saber del soberano y el saber oculto y animalista que acaba enterrado. Como indica Derrida (2010), el saber del soberano es un saber-hacer (con la fuerza del león o la tiranía del lobo) sin hacer-saber (con la astucia del zorro). La praxis de esas categorías de origen maquiavélico es confrontada por el lenguaje de devoración y carroña, del mundo reptil y rastrero de Figueroa, una fábula del hacersaber que expone al soberano, un voyeurismo que, solo oculto, protege a la crítica de volver a los tribunales. Es difícil determinar si en el hacer-saber del saber-hacer del poder intervino el hermano menor, Eusebio Figueroa, quien luego de sufrir el golpe de 1870, fue considerado por el régimen de Guardia para altos cargos públicos; si era esta una de las muchas cooptaciones de la dictadura, si la cercanía del hermano al poder provocó fugas en el secreto político o algún drama familiar, quedará como interrogante de otros estudios.

Así como se le atribuye la primicia en distintos campos del saber, la de Figueroa podría ser la historia temprana de una zoología política en el país; sin embargo, 
no se deriva de ello que esa metafórica animal, monstruosa y abyecta fuera resultado exclusivo, y por tanto temporal, del paréntesis autoritario. Su presencia a lo largo de la primera mitad del siglo XX vuelve borrosas las líneas de ese paréntesis; monstruos y animales no se extinguen con la democracia, más bien sólo parecen haber sido liberados de una jaula.

\section{Notas}

1 Véase por ejemplo a Demandt (1978), Peil (1983), Rigotti (1994) y Münkler (1994).

2 Sigo la misma vía del estudio de Manuel Vicuña (2008: 189-214) sobre el historiador chileno de fines del siglo XIX Benjamín Vicuña Mackenna quien, en la disputa por la identidad liberal, escribió biografías para el panteón de héroes de la patria, pero también una historia nacional de la infamia que contraponía a esos héroes unos personajes malditos, monstruos que borraban las fronteras del imaginario historiográfico y literario.

3 Véase Cabezas y Jiménez (2001), la obra de Arroyo (2006) y el libro colectivo de Acuña et al. (2011).

$4 \quad$ Dos de ellos publicados como Figuras y figurones en Figueroa (2010).

5 Véase Brenes (2005; 2010), Sáenz (2009), Arroyo (2009), Acuña et al. (2011), y los estudios introductorios a Figuras y figurones en Figueroa (2010).

6 En adelante, toda abreviatura "ANCR" se refiere a los Archivos Nacionales de Costa Rica.

7 Se ha conservado la ortografía original de toda la documentación consultada.

8 Véase la denuncia de "daños y perjuicios" a la que se sumó la de "injurias" durante el juicio, del cual Figueroa salió “sobreseído”, en ANCR (1890).

9 Véase los documentos del ANCR, Protocolos Notariales, $\mathrm{n}^{\circ}$ 30, escritura 3, tomo 12, 1891, fs.88v-89v; n 587, escritura 71, 1892, fs.7v-8v; n 43, escritura 71, tomo 25, 1895, fs.22-23; Juzgado Contencioso Administrativo, $n^{\circ}$ 5587, abril de 1900; $n^{\circ}$ 6460, abril de 1900; $n^{\circ} 6190$, agosto de 1900.

10 Sobre esto, véase Zavala (2006: VII-XXIV), Sanabria (1977: 162-163), de la Goublaye de Ménorval (2007), Sánchez (2002: 73-75; 2011), Ferrero (1986: 64-67) y Acuña (2009).

Sobre el caso colombiano, Acevedo (2009); sobre el mexicano, Barajas (2005) y Gantús (2009).

La Ley indicaba que no podía abusarse del anonimato; la religión del Estado no podía ofenderse; las autoridades y funcionarios públicos no debían ser ridiculizados con defectos privados; y la publicación o censura de sus actos y conductas debían ser probados bajo el riesgo de calumnia (Oficial, 1872).

La compaginación refiere al cuaderno rojo en Figuras y figurones (Figueroa, 2010).

Es también el caso, aunque legitimado en la historiografía positivista, del historiador chileno Benjamín Vicuña Mackenna (Vicuña, 2008). 
La invasión se realizó a fines de 1877 desde el Caribe nicaragüense e incluía costarricenses emigrados y hondureños dispuestos a derrocar a Guardia, pues Mora resentía la anulación de su elección como diputado suplente en marzo de 1872; detenida la invasión, debió refugiarse nuevamente en Nicaragua, cuyo Gobierno negó su participación en la insurrección y procuró evitar otros ataques (Chavarría, 1982).

\section{Bibliografía}

Acevedo, Darío. Política y caudillos colombianos en la caricatura editorial, 1920-1950. Medellín: La Carreta Editores-Universidad Nacional de Colombia, 2009.

Acuña, Víctor Hugo. "La invención de la diferencia costarricense, 1810-1870". Revista de Historia 45 (enero-junio 2002): 191-228.

. "El Álbum de Figueroa: rebeldía y fantasía en la Costa Rica del siglo XIX." La Nación, 9 de diciembre de 2009.

Acuña Ortega, Víctor H. et al. El Álbum de Figueroa. Un viaje por las páginas del tiempo. San José: EUNED-EUCR-EUNA-ET, 2011.

Acuña Ortega, Víctor Hugo. “El Álbum de Figueroa como artefacto cultural de la memoria costarricense". Varios autores. El Álbum de Figueroa. Un viaje por las páginas del tiempo. San José: EUNED-EUCR-EUNA-ET, (2011): 193-211.

Alvarado Venegas, Ileana y Efraín Hernández Villalobos. La animalística en el arte costarricense. San José: Fundación de Museos del Banco Central, 2006.

ANCR, Congreso, n ${ }^{\circ} 8945$, agosto de 1882.

ANCR, Congreso, $n^{\circ}$ 9025, setiembre de 1882.

ANCR, Congreso, no 8909, junio de 1884, fs.1-3.

ANCR, Expedientes Judiciales. Juzgado Segundo de Cartago, n 137, octubre de 1843.

ANCR, Expedientes Judiciales, n 30163, caja 852, 1890.

ANCR. Juzgado Contencioso Administrativo, $n^{\circ} 365$, febrero de 1860, fs.28-28v.

ANCR, Juzgado Contencioso Administrativo, n 5587, abril de 1900.

ANCR, Juzgado Contencioso Administrativo n 6460, abril de 1900.

ANCR, Juzgado Contencioso Administrativo, n 6190, agosto de 1900.

ANCR, Protocolos Notariales, $n^{\circ} 30$, escritura 3, tomo 12, 1891, fs.88v-89v.

ANCR, Protocolos Notariales, $n^{\circ} 587$, escritura 71, 1892, fs.7v-8v.

ANCR, Protocolos Notariales $n^{\circ} 43$, escritura 71, tomo 25, 1895, fs.22-23.

ANCR, Secretaría de Policía, n 5872, abril de 1855.

Arias Castro, Tomás Federico. Dr. Eusebio Figueroa Oreamuno: su derrotero e impronta en la historia decimonónica costarricense. San José: EUCR, 2011.

Arias Mora, Dennis. "Criaturas de lo heroico y lo monstruoso. Metáforas del saber biopolítico y sus cuerpos (Costa Rica, 1900-1946)". Tesis doctoral en Historia, Universidad Libre de Berlín, 2013.

Arroyo, Jorge. Figueroa, notario de la patria inédita. San José: EUNED, 2006. . "Nacimiento e infancia alajuelense de José María Figueroa Oreamuno". Revista Nacional de Cultura, 57 (2009a): 43-52.

"Llorados duelos antiguos". La Nación, 31 de mayo de 2009b. 
Barajas Durán, Rafael. El país de "El Ahuizote". La caricatura mexicana de oposición durante el gobierno de Sebastián Lerdo de Tejada (1872-1876). México: FCE, 2005.

Blumenberg, Hans. La legibilidad del mundo. Barcelona: Paidós, 2000.

Bravo Lira, Bernardino. "Bicentenario del Código Penal de Austria. Su proyección desde el Danubio a Filipinas". Revista de estudios histórico-jurídicos, 26 (2004): 115-155.

Brenes Tencio, Guillermo. "Libelos y dibujos escandalosos en el Cartago de 1843". Revista Nacional de Cultura, 49 (abril 2005): 51-54.

"Tres momentos en la vida del joven y díscolo José María Figueroa Oreamuno". Umbral, 26 (2010): 45-52.

Cabezas Bolaños, Esteban y Jorge Emilio Jiménez. El álbum de Figueroa: el interés de un hombre por plasmar en un documento archivístico la evolución histórico-social costarricense (Catálogo de álbum). San José: sin editorial, 2001.

Chavarría Arroyo, Dunia. "Segunda dictadura de don Tomás Guardia". Tesis de licenciatura en Historia, Universidad de Costa Rica, 1982.

Cóver Jiménez, Edgar. "Esbozo histórico de la obra de gobierno de don Tomás Guardia". Tesis de Licenciatura en Historia, Universidad de Costa Rica, 1982.

de La Goublaye de Ménorval, Yves. “Exposición documental Genealogía: a la búsqueda de una identidad". Boletín electrónico de la Academia Costarricense de Ciencias Genealógicas 86 (octubre 2007). <http://www.genealogia.or.cr/pdf/boletines/ACCG-boletin086.pdf>.

Demandt, Alexander. Metaphern für Geschichte. Sprachbilder und Gleichnisse im historisch-politischen Denken. München: C. H. Beck, 1978.

Derrida, Jacques. Seminario La bestia y el soberano. Volumen I (2001-2002). Buenos Aires: Manantial, 2010.

Díaz, Ronald. "La ciencia y el debate entre la Iglesia Católica y el liberalismo en CR (18801901)". Diálogos 7.2 (setiembre 2006-febrero, 2007). <http://www.historia.fcs.ucr.ac.cr/>.

Díaz Arias, David. Construcción de un Estado moderno. Politica, Estado e identidad nacional en Costa Rica, 1821-1914. San José: EUCR, 2005.

El Comercio de Costa Rica, 25 de diciembre de 1870: 1.

El Gato, 11 de julio de 1889a: 1-2.

El Gato, 11 de julio de 1889b: 2-3.

El Pueblo, 3 de enero de 1878: 1.

El Pueblo, 25 de enero de 1878: 1.

Fallas Jiménez, Lisbeth y Myriam Sequeira Enríquez. "La política de don Tomás Guardia en Centro América". Tesis de Licenciatura en Historia, Universidad de Costa Rica, 1976.

Fallas Santana, Carmen María. “La voluntad de la Nación y la regeneración política: Los pronunciamientos militares de 1859, 1868 y 1870 en Costa Rica". Diálogos 9.2 (agosto 2008-febrero 2009). <http://historia.fcs.ucr.ac.cr/articulos/2008/vol2/03carmenfallasp ronunciamientos.pdf $>$.

Ferrero, Luis. Sociedad y arte en la Costa Rica del siglo XIX. San José: EUNED, 1986.

Figueroa, José María. Figuras y figurones. San José: Fundación Escuela para todos, 2010.

Fonseca, Pablo. “"'Álbum de Figueroa” declarado patrimonio documental del mundo". La Nación, 11 de diciembre de 2009.

"Archivo Nacional pide entrega de cuadernos de Figueroa". La Nación, 20 de abril de 2010.

Foucault, Michel. La vida de los hombres infames. La Plata: Editorial Altamira, 1996. . Defender la sociedad (Curso en el Collège de France (1975-1976)). Buenos Aires: FCE, 2001. 
El nacimiento de la biopolitica. Curso en el Collège de France (1978-1979). Buenos Aires: Fondo de Cultura Económica, 2008.

Gantús, Fausta. Caricatura y poder político. Crítica, censura y represión en la ciudad de México, 18761888. México: El Colegio de México, 2009.

Goebel McDermott, William Anthony. "Naturaleza imaginada. Una aproximación a las representaciones sociales de la naturaleza en la Costa Rica decimonónica. Un estudio de caso: los exploradores extranjeros (1850-1905)". Tesis de Maestría en Historia, Universidad de Costa Rica, 2007.

. "Historiar con el prisma "verde". El Álbum de Figueroa como fuente para el estudio de la historia ambiental costarricense: temas, problemas y perspectivas". Varios autores. El Álbum de Figueroa. Un viaje por las páginas del tiempo. San José: EUNED-EUCREUNA-ET, 2011. 68-97.

González García, José M. Metáforas del poder. Madrid: Alianza editorial, 1998.

Kristeva, Julia. Poderes de la perversión. México: Siglo XXI editores, 2006.

Macho, Thomas. "Gute Hirten, schlechte Hirten. Zu einem Leitmotiv politischer Zoologie". Anne Von der Heiden y Anne und Joseph Vogl (eds.). Politische Zoologie. Berlin-Zürich: Diaphanes, 2007. 71-88.

Malavassi Aguilar, Ana Paulina. "Perfil socioeconómico y judicial de los ociosos, vagabundos y malentretenidos en el Valle Central de Costa Rica, 1750-1850". Ronny Viales Hurtado (ed.). Pobreza e historia en Costa Rica. Determinantes estructurales y representaciones sociales del siglo XVII a 1950. San José: EUCR, 2005. 21-51.

Meléndez, Carlos (comp.). Mensajes presidenciales 1859-1885. San José: Biblioteca de la Academia de Geografía e Historia, 1981a. . Mensajes presidenciales 1885-1906. San José: Biblioteca de la Academia de Geografía e Historia de Costa Rica, 1981b.

Molina Jiménez, Iván. Ricardo Jiménez. San José: EUNED, 2009.

Münkler, Herfried. Politische Bilder, Politik der Metaphern. Frankfurt am Main: Fischer Verlag, 1994.

Oficial. Reglamento para el gobierno interior de las imprentas del estado. San José: Imprenta del Estado, 1846.

Oficial. Código General de la República de Costa-Rica, emitido en 30 de julio de 1841. Nueva York: Imprenta de Wyukoop, Hallenbeck and Thomas, 1858.

Oficial. Ley de Imprenta (1872). Versión en línea. San José, Procuraduría General de la República. $<$ http://www.pgr.go.cr/>.

Pedraza Gómez, Zandra. “El régimen biopolítico en América Latina. Cuerpo y pensamiento social". Iberoamericana IV.15 (2004): 7-19.

Peil, Dietmar. Untersuchungen zur Staats- und Herrschaftsmetaphorik in literarischen Zeugnissen von der Antike bis zur Gegenwart. München: Wilhelm Fink, 1983.

Rigotti, Francesca. Die Macht und ihre Metaphern. Über die sprachlichen Bilder der Politik. Frankfurt-New York: Campus, 1994.

Román González, José Pablo. “Nuevo bestiario costarricense: Reescritura de la imagen gráfica del monstruo tico en la actualidad". San José: Tesis de Licenciatura en Artes Plásticas, Universidad de Costa Rica, 2009.

Sáenz Shelby, Gabriela. “Costa Rica: colonia y nación en la mirada de José María Figueroa Oreamuno (1820-1900)". Diálogos, 10.1 (febrero-agosto2009). <http://historia.fcs.ucr. ac.cr/articulos/2009/vol1/06gsaenzalbum.html>. 
“Figuras y Figurones de Figueroa: las imágenes de un soliloquio". José María Figueroa, Figuras y Figurones. San José: Fundación Escuela para todos, 2010. 176-185.

Sanabria, Víctor M. "Genealogías de Cartago hasta 1850”. Luis Demetrio Tinoco. Población de Costa Rica y orígenes de los costarricenses. San José: Editorial Costa Rica, 1977.

Sánchez Lovell, Adriana. "La vagancia en tiempos del café y la caña: sueños, luchas y desencantos ante la obligación de trabajar en Costa Rica". Tesis de Maestría en Historia, Universidad de Costa Rica, 2013.

Sánchez Molina, Ana Cecilia. Caricatura y prensa nacional. Heredia: EUNA, 2002. . "Ese pícaro de José María Figueroa". La Nación, 27 de noviembre de 2011.

Urbina Gaitán, Chester. "Homogeneizando culturas. Peleas de gallos, corridas de toros y estado en Costa Rica (1870-1914)." Revista de Ciencias Sociales 89 (2000): 59-67.

Vargas González, Hugo. "Evolución del sistema electoral costarricense (1859-1870)". Diálogos, 2.2 (enero-abril 2001). <http://historia.fcs.ucr.ac.cr/articulos/ev-elec.htm>.

Vega Jiménez, Patricia. De la imprenta al periódico: los inicios de la comunicación impresa en Costa Rica. 1821-1950. San José: Porvenir, 1995.

. "De periodista a literato. Los escritores de periódicos costarricenses (1870-1890)". Anuario de Estudios Centroamericanos, 22.1 (1996): 149-163.

. "Una audiencia en crecimiento. La prensa en Costa Rica (1872-1889)". Revista de Ciencias Sociales, 86-87 (1999): 139-155.

Vicuña, Manuel. “El bestiario del historiador: las biografías de „monstruos" de Benjamín Vicuña Mackenna y la identidad liberal como un bien en disputa". Historia 41.1 (enerojunio, 2008): 189-214.

von der Heiden, Anne y Joseph Vogl. "Vorwort". Anne Von der Heiden y Joseph Vogl (Eds.), Politische Zoologie. Berlin-Zürich: Diaphanes, 2007. 7-12.

Zavala, Magda. "José María Figueroa y Jorge Arroyo: en busca de una mayor elocuencia de la historia". Jorge Arroyo. Figueroa: notario de la patria inédita. San José: EUNED, 2006. VII-XXIV.

Dennis Arias Mora. Costarricense. Doctor en Historia por la Universidad Libre de Berlín, Alemania. Máster en Historia por la Universidad de Costa Rica. Profesor en la Escuela de Historia e investigador en el Centro de Investigaciones en Identidad y Cultura Latinoamericanas (CIICLA), ambos de la Universidad de Costa Rica.

Contacto: dennarm@yahoo.de 